Original Article

\title{
Gut dysbiosis, inflammation and type 2 diabetes in mice using synthetic gut microbiota from diabetic humans
}

\author{
Disbiose intestinal, inflamação e diabetes tipo 2 em camundongos usando microbiota \\ intestinal sintética de humanos diabéticos
}

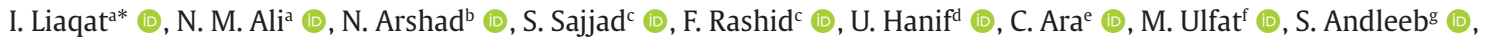

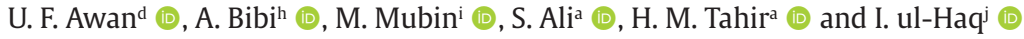 \\ aGC University Lahore, Department of Zoology, Microbiology Laboratory, Lahore, Pakistan \\ ${ }^{\mathrm{b}}$ The University of Lahore, Department of Zoology, Lahore, Pakistan \\ cLahore College for Women University, Department of Zoology, Lahore, Pakistan \\ dGC University, Department of Botany, Lahore, Pakistan \\ eUniversity of the Punjab, Department of Zoology, Lahore, Pakistan \\ fLahore College for Women University, Department of Botany, Lahore, Pakistan \\ gUniversity of Azad Jammu and Kashmir, Department of Zoology, Muzaffarabad, Pakistan \\ hThe Women University, Department of Zoology, Multan, Pakistan \\ iUniversity of Agriculture, Centre of Agricultural Biochemistry and Biotechnology, Faisalabad, Pakistan \\ jGC University, Institute of Industrial Biotechnology, Lahore, Pakistan
}

\begin{abstract}
The study was aimed to assess impact of high fat diet (HFD) and synthetic human gut microbiota (GM) combined with HFD and chow diet (CD) in inducing type-2 diabetes (T2D) using mice model. To our knowledge, this is the first study using selected human GM transplantation via culture based method coupled dietary modulation in mice for in vivo establishment of inflammation leading to T2D and gut dysbiosis. Twenty bacteria (T2D1-T2D20) from stool samples of confirmed T2D subjects were found to be morphologically different and subjected to purification on different media both aerobically and anerobically, which revealed seven bacteria more common among 20 isolates on the basis of biochemical characterization. On the basis of 16S rRNA gene sequencing, these seven isolates were identified as Bacteroides stercoris (MT152636), Lactobacillus acidophilus (MT152637), Lactobacillus salivarius (MT152638), Ruminococcus bromii (MT152639), Klebsiella aerogenes (MT152640), Bacteroides fragilis (MT152909), Clostridium botulinum (MT152910). The seven isolates were subsequently used as synthetic gut microbiome (GM) for their role in inducing T2D in mice. Inbred strains of albino mice were divided into four groups and were fed with CD, HFD, GM+HFD and GM+CD. Mice receiving HFD and GM+modified diet (CD/HFD) showed highly significant $(\mathrm{P}<0.05)$ increase in weight and blood glucose concentration as well as elevated level of inflammatory cytokines (TNF- $\alpha$, IL-6, and MCP-1) compared to mice receiving CD only. The 16S rRNA gene sequencing of 11 fecal bacteria obtained from three randomly selected animals from each group revealed gut dysbiosis in animals receiving GM. Bacterial strains including Bacteroides gallinarum (MT152630), Ruminococcus bromii (MT152631), Lactobacillus acidophilus (MT152632), Parabacteroides gordonii (MT152633), Prevotella copri (MT152634) and Lactobacillus gasseri (MT152635) were isolated from mice treated with GM+modified diet (HFD/ CD) compared to strains Akkermansia muciniphila (MT152625), Bacteriodes sp. (MT152626), Bacteroides faecis (MT152627), Bacteroides vulgatus (MT152628), Lactobacillus plantarum (MT152629) which were isolated from mice receiving $\mathrm{CD} / \mathrm{HFD}$. In conclusion, these findings suggest that constitution of GM and diet plays significant role in inflammation leading to onset or/and possibly progression of T2D. .
\end{abstract}

Keywords: type 2 diabetes, high fat diet, gut microbiota, in vivo study, inflammatory markers.

\begin{abstract}
Resumo
O estudo teve como objetivo avaliar o impacto da dieta rica em gordura (HFD) e da microbiota intestinal humana sintética (GM) combinada com HFD e dieta alimentar (CD) na indução de diabetes tipo 2 (T2D) usando modelo de camundongos. Para nosso conhecimento, este é o primeiro estudo usando transplante de GM humano selecionado através do método baseado em cultura acoplada à modulação dietética em camundongos para o estabelecimento in vivo de inflamação que leva a T2D e disbiose intestinal. Vinte bactérias (T2D1-T2D20) de amostras de fezes de indivíduos T2D confirmados verificaram ser morfologicamente diferentes e foram submetidas à purificação em meios diferentes aerobicamente e anaerobicamente, o que revelou sete bactérias mais comuns entre 20 isolados
\end{abstract}

*e-mail: iramliaq@hotmail.com

Received: September 16, 2020 - Accepted: February 11, 2021 
com base na caracterização bioquímica. Com base no sequenciamento do gene $16 \mathrm{~S}$ rRNA, esses sete isolados foram identificados como Bacteroides stercoris (MT152636), Lactobacillus acidophilus (MT152637), Lactobacillus salivarius (MT152638), Ruminococcus bromii (MT152639), Klebsiella aerogenides (MT152640), Bacteroides fragilis (MT152909), Clostridium botulinum (MT152910). Esses sete isolados foram, posteriormente, usados como microbioma intestinal sintético (GM) por seu papel na indução de T2D em camundongos. Linhagens consanguíneas de camundongos albinos foram divididas em quatro grupos e foram alimentadas com CD, HFD, GM + HFD e GM + CD. Camundongos que receberam a dieta modificada com HFD e GM + (CD / HFD) mostraram um aumento altamente significativo $(\mathrm{P}<0,05)$ no peso e na concentração de glicose no sangue, bem como um nível elevado de citocinas inflamatórias (TNF- $\alpha$, IL-6 e MCP-1) em comparação com os ratos que receberam apenas CD. O sequenciamento do gene $16 \mathrm{~S}$ rRNA de 11 bactérias fecais obtidas de três animais selecionados aleatoriamente de cada grupo revelou disbiose intestinal em animais que receberam GM. Cepas bacterianas, incluindo Bacteroides gallinarum (MT152630), Ruminococcus bromii (MT152631), Lactobacillus acidophilus (MT152632), Parabacteroides gordonii (MT152633), Prevotella copri (MT152634) e Lactobacillus Gasseri (MT152635D), foram tratadas com dieta modificada / CD) em comparação com as linhagens Akkermansia muciniphila (MT152625), Bacteriodes sp. (MT152626), Bacteroides faecis (MT152627), Bacteroides vulgatus (MT152628), Lactobacillus plantarum (MT152629), que foram isoladas de camundongos recebendo CD / HFD. Em conclusão, esses resultados sugerem que a constituição de GM e dieta desempenham papel significativo na inflamação levando ao início ou/e possivelmente à progressão de T2D.

Palavras-chave: diabetes tipo 2, dieta rica em gordura, microbiota intestinal, estudo in vivo, marcadores inflamatórios.

\section{Introduction}

Among metabolic disorders, type 2 diabetes mellitus (T2D) has attained global attention due to its increasingly high occurrence. Insulin resistance and low-grade inflammation are the most important pathogenic factors associated with T2D. Various studies have tested the potential of medicinal plants for their antidiabetic potential (Regginato et al., 2021). The onset of T2D is affected by both genetic and environmental factors. The gut barrier which is affected both by gut microbiota (GM) and energy rich foods such as high fat diet (HFD) are most important factors that influences T2D development by increased activation of the inflammatory pathways, metabolic disorders and metabolic endotoxemia (Everard and Cani, 2013; Sircana et al., 2018; Canfora et al., 2019). The cross talk between GM, host and HFD has become a research subject of great interest in recent decades.

Both T2D and the gut are very closely related (Canfora et al., 2019). Importance of GM can be judged by the fact that it performs many significant functions in immunity, breakdown of indigestible carbohydrates and maintenance of intestinal wall (Everard and Cani, 2013). Studies using T2D patients and mice have confirmed that GM variations control partial onset and progression of disease (Qin et al., 2012; Greiner et al., 2014). Host diet, genotype and health status controls GM diversity. Gut microbial community altered entirely by dietary modulations such as increased uptake of HFD, is a new era of study which investigates its association with metabolic diseases. Both high-fat and high-sucrose feeding have been reported to induce phylum level shifts (Parks et al., 2013). Vrieze et al. (2012) reported that 6 weeks transplantation of fecal bacteria from lean to obese individuals resulted in significant alteration in intestinal microbial diversity, leading to increased uptake of glucose and sensitivity to insulin. If any disturbance occurs in delicate balance between microbial consortia and host, it may result in gut "dysbiosis" and onset of T2D in host (Bhute et al., 2017).

T2D patients have an altered composition of GM, particularly a decreased number of beneficial bacteria such as Bifidobacteria and increase in pathogens and endotoxins releasing bacteria (Cani et al., 2009). Consequently, altered microbiota modulates intestinal permeability and results in increased secretions of metabolic endotoxins (lipopolysaccharides, peptidoglycans and flagellin) that cause T2D (Cani et al., 2009; Greiner et al., 2014). Additionally, in T2D patients, the number of butyrate producing bacteria viz., Eubacterium rectale, Clostridium sp., Roseburia intestinalis and Faecalibacterium prausnitzii decluines (Qin et al., 2012; Karlsson et al., 2013). Bacteria that reduce sulfur such as Desulfovibrio and Lactobacillus sp. (L. gasseri, L. reuteri and L. plantarum) are found to be increased in intestine (Karlsson et al., 2013).

Mechanisms by which GM plays important role in host physiology and endocrine are not fully understood. However, it has been established that GM interacts with host using both nervous and endocrine routes. Various GM metabolites such as bioactive lipids, serotonin, bile acids, and short chain fatty acids synchronize host physiological and pathological mechanisms, controlling appetite, energy intake and oxidation of lipid (Rastelli et al., 2018; Canfora et al., 2019). The gut dysbiosis leads to production of inflammatory factors including cytokines and endotoxins etc., in the body (Marchesi et al., 2016), underlying mechanisms of which are still less explored.

Interaction between HFD, GM and their combined effect on host well being needs further research. Therefore, the current study was conducted to examine the impact of HFD and T2D associated human GM on inflammatory cytokines and induction of T2D. Furthermore, we also checked if it caused any imbalance in intestinal microflora of mice. This study will provide valuable insights into role of gut community and dietary approaches for better understanding and prevention of T2D.

\section{Materials and Methods}

\subsection{Experimental design and sample collection}

This study was approved by institutional bioethics committee, GC University, Lahore vide letter no. $3454 / 08 / 19$ dated 22/08/2019. Figure 1 illustrates complete experimental design of the study. Briefly, 10 subjects diagnosed with type 2 diabetes (T2D) and 10 clinically 


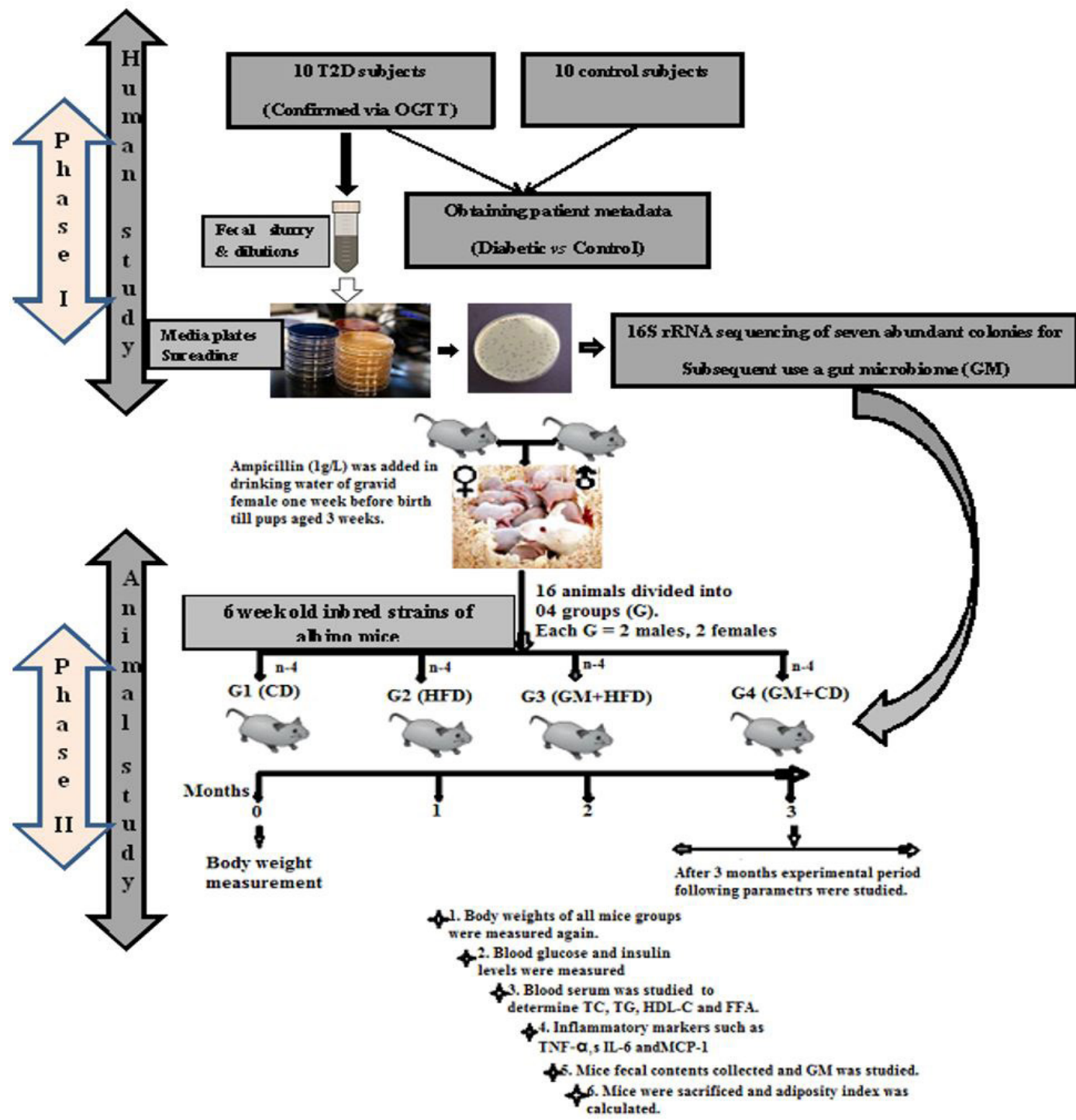

Figure 1. The experimental design of type 2 diabetic (T2D) patients and mouse model. In Phase I, twenty subjects including type 2 diabetes (T2D) and control participated in study. After comparing metadata of diabetic $v s$ control, further study focused on T2D subjects only. Fecal bacteria were plated on different media plates aerobically and anaerobically. On the basis of visual inspection, seven different but abundant strains were identified by $16 \mathrm{~S}$ rRNA sequencing and mixed equally to prepare human synthetic gut microbiota (GM). In phase II, inbred strains of albino mice were mated and ampicillin $(1 \mathrm{~g} / \mathrm{L})$ was added in drinking water of gravid female one week before birth till pups aged three weeks. Afterwards 16 mice were divided into four groups (G1-G4), each comprising of 2 males and 2 females $(n=4)$. G1 was fed with chow diet (CD), G2 with high fat diet (HFD), G3 with GM+HFD and G4 with GM+CD. Body weight was measured at start and end of experiment. Rest all parameters were measured after three months experimental period.

healthy subjects confirmed by their general practitioner using oral glucose tolerance test (OGTT) were included in this study. Sociodemographic, clinical and anthropometric data were collected from all participants by means of purposely designed questionnaires and personal interview (Table 1). Informed consent was obtained from all participants of the study. The OGTT included the measurements of plasma glucose $(\mathrm{mg} / \mathrm{dl})$ at baseline and two hours after administration of $75 \mathrm{~g}$ glucose dissolved in $500 \mathrm{~mL}$ of water. Fecal samples were collected and taken to the Microbiology laboratory of department. During transportation, the temperature of $5{ }^{\circ} \mathrm{C}$ was maintained. Fecal samples were stored in container supplemented with GasPak generator (Becton Dickinson, Sparks, MD, United States) and enclosed in zipper bag. For isolation of fecal bacteria, container was opened in sterile hood, exposed to oxygen for one and half hour. Fecal slurry was made by homogenizing in pre-reduced phosphate buffer saline (PBS), filtration and various dilutions $\left(10^{-1}\right.$ to $\left.10^{-10}\right)$ were prepared. Ten $\mu$ l of dilution were spread on various agar media (MacConkey agar, Tryptone Soy Agar (TSA), Xylose Lysine Deoxycholate agar (XLD), and Nutrient Agar(NA) and 
Table 1. The sociodemographic, clinical and anthropometric characteristics of study participants.

\begin{tabular}{|c|c|c|c|c|c|c|c|c|c|c|}
\hline \multicolumn{11}{|c|}{ Diabetic (D) subjects (N=10) } \\
\hline Parameters & D1 & D2 & D3 & D4 & D5 & D6 & D7 & D8 & D9 & D10 \\
\hline Sex & M & M & M & M & M & $\mathrm{F}$ & $\mathrm{F}$ & $\mathrm{F}$ & $\mathrm{F}$ & $\mathrm{F}$ \\
\hline Age (Years) & 36 & 40 & 55 & 65 & 70 & 37 & 45 & 60 & 68 & 75 \\
\hline Weight (Kg) & 67 & 70 & 75 & 90 & 95 & 65 & 89 & 95 & 92 & 97 \\
\hline Hypertension & Yes & yes & yes & yes & yes & yes & yes & yes & yes & yes \\
\hline Ethnicity & Asian & Asian & Asian & Asian & Asian & Asian & Asian & Asian & Asian & Asian \\
\hline Smoking & No & No & yes & yes & yes & No & No & No & No & No \\
\hline Marital status & Married & Married & Married & Married & Married & Married & Married & Married & Widow & Widow \\
\hline Education level & Illiterate & Illiterate & Illiterate & Literate & Literate & Literate & Literate & Illiterate & Illiterate & Illiterate \\
\hline $\begin{array}{c}\text { Duration of } \\
\text { diabetes (years) }\end{array}$ & $\leq 7$ & $>7$ & $>7$ & $>7$ & $>7$ & $\leq 7$ & $\leq 7$ & $>7$ & $>7$ & $>7$ \\
\hline $\begin{array}{c}\text { Management of } \\
\text { diabetes }\end{array}$ & $\mathrm{OA}$ & $\mathrm{OA}$ & $\mathrm{OA}$ & Insulin & Insulin & $\mathrm{OA}$ & $\mathrm{OA}$ & $\mathrm{OA}$ & $\mathrm{OA}$ & Insulin \\
\hline \multicolumn{11}{|c|}{ Control (C) Subjects ( $N=10)$} \\
\hline Parameters & C1 & C2 & C3 & C4 & C5 & C6 & C7 & C8 & C9 & C10 \\
\hline Sex & M & M & M & M & M & $\mathrm{F}$ & $\mathrm{F}$ & $\mathrm{F}$ & $\mathrm{F}$ & $\mathrm{F}$ \\
\hline Age (Years) & 35 & 41 & 53 & 67 & 73 & 36 & 48 & 55 & 65 & 74 \\
\hline Weight (Kg) & 66 & 72 & 76 & 91 & 97 & 67 & 87 & 93 & 95 & 97 \\
\hline Hypertension & Yes & yes & yes & No & No & yes & yes & No & No & No \\
\hline Ethnicity & Asian & Asian & Asian & Asian & Asian & Asian & Asian & Asian & Asian & Asian \\
\hline Smoking & No & No & No & No & yes & No & No & No & No & No \\
\hline Marital status & Single & Married & Married & Married & Married & Married & Married & Married & Married & Widow \\
\hline Education level & Literate & Literate & Literate & Illiterate & Illiterate & Literate & Literate & Illiterate & Illiterate & Illiterate \\
\hline $\begin{array}{c}\text { Duration of } \\
\text { diabetes (years) }\end{array}$ & NA & NA & NA & NA & NA & NA & NA & NA & NA & NA \\
\hline $\begin{array}{l}\text { Management of } \\
\text { diabetes }\end{array}$ & NA & NA & NA & NA & NA & NA & NA & NA & NA & NA \\
\hline
\end{tabular}

$\mathrm{M}=$ male; $\mathrm{F}=$ Female; $\mathrm{OA}$ = oral antidiabetic medicine; $\mathrm{NA}=$ Not applicable.

Blood Agar) and incubated under aerobic and anaerobic conditions (using a GasPak ${ }^{\circledR}$ system) at $37{ }^{\circ} \mathrm{C}$. Oxygen level was observed to be $1.3 \%$ and remained constant after placing plates. Colonies appeared were counted, purified and stored ( $20 \%$ glycerol and $5 \%$ skim milk) at $-80^{\circ} \mathrm{C}$.

\subsection{DNA purification and $16 \mathrm{~S}$ rRNA sequencing}

Genomic DNA was isolated from visibly seven different abundantly common bacteria using Qiagen stool Mini Kit (Germany) following manufacturer's instructions. The DNA concentration was determined using nano-drop and 16S rRNA gene amplification was performed using primers (16S-27F 5'-AGAGTTTGATCCTGGCTCAG-3') and (16S-1522R 5'- AAGGAGGTGATCCAGCCGCA-3') under standard conditions. PCR reaction mixture consisted of $10 \times$ PCR Buffer $5 \mu \mathrm{l}, 4 \times \mathrm{dNTPs}(10 \mathrm{mmol} / \mathrm{l}) 4 \mu \mathrm{l}$, TaqDNA polymerase $(5 \mathrm{U} / \mu \mathrm{l}) 0.5 \mu \mathrm{l}$, upstream and downstream primer (concentration, $50 \mu \mathrm{mol} / l$ ) each $1 \mu \mathrm{l}$, template $1 \mu \mathrm{l}$, and ultra-pure water to a final volume of $50 \mu$ l. The reaction conditions were: $95{ }^{\circ} \mathrm{C}$ denaturation for $5 \mathrm{~min}, 35$ cycles of $94{ }^{\circ} \mathrm{C}$ denaturation $1 \mathrm{~min}, 53-55^{\circ} \mathrm{C}$ annealing $1 \mathrm{~min}$, $72{ }^{\circ} \mathrm{C}$ extension $1 \mathrm{~min}$ and a final extension at $72^{\circ} \mathrm{C}$ for 10 min. Purified PCR products were sequenced using Sanger method. Using $16 \mathrm{~S}$ rRNA gene sequence database on NCBI BLAST website, isolates were taxonomically identified upto species level on the basis of E-value. Phylogenetic tree was constructed using MEGA X software and the genetic distance of each strain was determined.

\subsection{Animal housing}

The experiment was approved by the institutional bioethics committee via Approval number IBC-3454/08/19 following guidelines designed by committee for the purpose of control and supervision of experiments on animals, Pakistan. Inbred strains of albino mice were taken and allowed to mate under temperature-controlled conditions $\left(22^{\circ} \mathrm{C}\right)$. Following modification of protocol by Ellekilde et al. (2014), ampicillin $(1 \mathrm{~g} / \mathrm{L})$ was mixed in drinking water of gravid female from one week before birth and addition was continued until pups were aged three weeks. Antibiotic 
treatment was given to deplete majority of existing gut microbiota in mice gut. A total of 16 model animals were divided in ratio of 8 males and 8 females into 4 groups. Each group consisted of 4 mice in equal ratio of males and females. Two mice were kept in each cage comprising of both males and females. Two types of diets viz. chow diet (CD; Cargill Animal Nutrition, MN, USA) and high fat diet (HFD; Research Diets Inc., New Brunswick, NJ, USA) were used in the study. Diets were irradiated with $\gamma$-rays (10 kGrays) for eliminating microbes and prevention of spoilage. Mice were fed with CD (G1); $\operatorname{HFD}(G 2)$; GM+HFD (G3) and GM+CD (G4) (Figure 1).

\subsection{High fat diet feeding and gut microbiota transfer}

HFD feeding and GM transfer was started at the age of 6 weeks and continued for further 12 weeks. The caloric content of HFD was $13 \%$ protein, $6 \%$ carbohydrate and $81 \%$ fats. The fat content of this diet was derived from $55 \%$ saturated fats, $37 \%$ monounsaturated fats and $8 \%$ polyunsaturated fats. Similarly, the energy content of CD comprised of $20 \%$ protein, $70 \%$ carbohydrate and $10 \%$ fats.

The model mice from group 3 and 4 were colonized with the synthetic GM by oral gavage in suspension form (inoculum). The bacterial inoculum was prepared by taking seven $16 \mathrm{~S}$ rRNA identified fecal bacteria $\left(\mathrm{OD}_{600} \pm\right.$ 0.1 ) and diluting in $1: 10$ in PBS (approximately $10^{6} \mathrm{CFU} /$ $\mathrm{mL}$ ). These seven isolates were observed to be abundantly found in feces of T2D patients on the basis of biochemical characterization (Data not shown). The prepared inoculum $(1 \mathrm{~mL})$ was given six times using gastric gavage during the 3 months experimental period.

\subsection{Body weight and adiposity index}

During the study, body weights of mice were measured at the start and end of experiment. Tissues, including perirenal fat and epididymal fat were excised and weighed. Following An et al. (2018), the adiposity index was calculated using Formula 1:

$$
[(\text { Epididymal }+ \text { Perirenal fat weight }) / \text { body weight }] \times 100
$$

\subsection{Measurement of glucose homeostasis}

Following 3 months experimental period (mice age: 18 weeks), blood glucose and plasma insulin levels of different groups were measured in fasting condition and after glucose challenge.

Briefly, for OGTT, mice were fasted for six hours and blood glucose was measured using a handheld glucometer. The mice were then challenged with an oral dose of glucose @ $3 \mathrm{~g} / \mathrm{kg}$ (Wu et al., 2019). Blood glucose was determined with a glucometer (Roche Diagnostics) using blood from the tail vein at $0,15,30$ and 60 minutes (Wu et al., 2019).

\subsection{Blood serum study}

After three months period, mice were fasted for 12 hours and sacrificed by cardiac puncture. Blood was allowed to clot for $30 \mathrm{~min}$ and centrifuged at $3000 \mathrm{rpm}$ for $15-20 \mathrm{~min}$. Serum was isolated and stored at $-20^{\circ} \mathrm{C}$ until analysis. Total cholesterol (TC), triglycerides (TG) and high-density lipoprotein (HDL-C) were detected using automatic analyzer (OLYMPUS AU5421). Free fatty acids (FFA) were measured using enzymatic assay (Clinimate NEFA, Tokyo, Japan).

\subsection{Determination of inflammatory factors}

Inflammatory factors including TNF- $\alpha$, IL-6, and MCP-1 were measured using ELISA kit ( $R$ and D Systems; Minneapolis, MN, USA).

\subsection{Analysis of mice gut microbiota}

At the end of experimental period, fecal contents were collected separately from all four groups and spread on various media plates as mentioned in section 2.1. GM from mice was analyzed by $16 \mathrm{~S}$ rRNA gene sequencing of three randomly selected morphologically different strains from each group. Briefly, genomic DNA was isolated separately from 12 fecal bacteria using Qiagen fecal Mini Kit (Germany), quantified, normalized to $1 \mathrm{ng} /$ $\mu \mathrm{l}$ in a centrifuge tube and used as template. Following optimization, 16S rRNA gene fragments were amplified using primers 341F: 5'-CCTACGGGNGGCWGCAG-3' and 805R: 5'-GACTACHVGGGTATCTAATCC-3'. Obtained fragments were purified using Gen elute Kit and sequenced. Using NCBI BLAST website, sequences were blast and strains were identified upto taxonomically on the basis of E-value. Phylogenetic tree was constructed and the genetic distance of each strain was determined as mentioned above in section 2.2 .

\subsection{Statistical analysis}

All values were expressed as means \pm SEM (standard error of mean). Student t-test (Paired t-test) was used to determine statistically significant differences in measured parameters for all groups before and after the experiment. One-way analysis of variance (ANOVA) with post hoc Tukey test using the SPSS statistical software (version 23) was used to determine the independent effect of CD, HFD, GM and their interaction on the serological parameters. Bars with different superscripts show data statistically Differences were considered significant at $\mathrm{p} \leq 0.05$.

\section{Results}

Patients with T2D and control with age range of 35 to 75 years and body mass index (BMI) ranging from 23 to 48 were selected. The mean age observed for diabetic and non-diabetic group was 53 and 55 respectively. The diabetic patients showed elevated concentration of plasma glucose (330-475 mg/dL) as measured by OGTT compared to control subjects (70-100 mg/dL) (Figure 2). Control subjects were included only for comparison with diabetic group to obtain sociodemographic, clinical and anthropometric data (Table 1). Further detailed study was carried out on stool samples of ten confirmed T2D subjects only. 

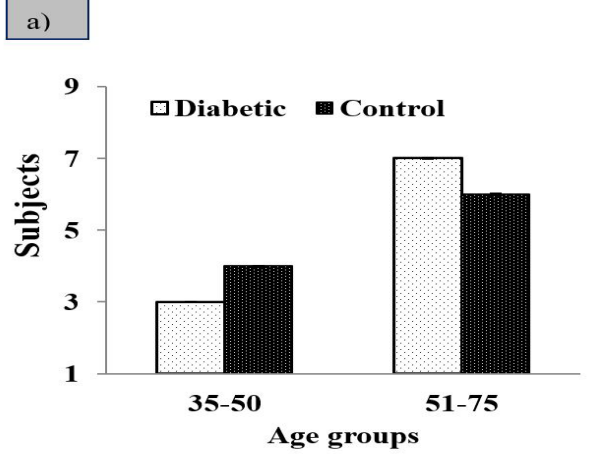

b)

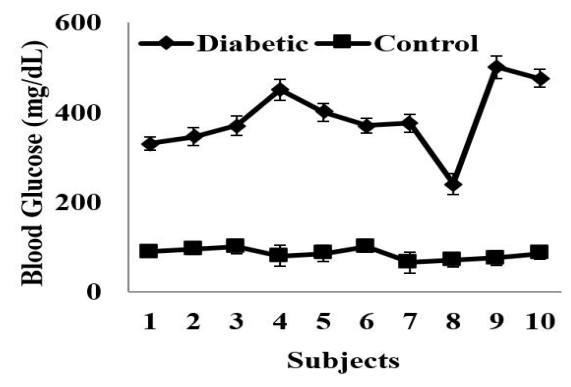

Figure 2. (a) Age wise distribution of study participants. The mean age observed for diabetic and non-diabetic group was 53 and 55 respectively (b). Blood glucose in diabetics and control subjects. The diabetic patients showed elevated concentration of plasma glucose (330-475 mg/dL) as measured by OGTT compared to control subjects $(70-100 \mathrm{mg} / \mathrm{dL})$. The data was expressed as mean \pm SEM ( $\mathrm{n}=3$ ).

\subsection{Morphological, physiological and biochemical characteristics of bacteria}

In total, 45 colonies were obtained from stool samples of 10 T2D patients. Most of the colonies of isolated strains were of yellow, pale yellow colour, golden yellow or transparent. Twenty purified strains showed variations in shape, margins and elevation, however convex shape and flat elevation was also observed in some colonies. Among these bacterial isolates, $30 \%$ strains were Gram positive while $70 \%$ strains were Gram negative. Growth on different media (MacConkey, TSA, XLD, NA and blood agar) showed seven colonies more abundant among fecal isolates.16S rRNA gene sequencing identified these seven isolates as Bacteroides stercoris (MT152636), Lactobacillus acidophilus (MT152637), Lactobacillus salivarius (MT152638), Ruminococcus bromii (MT152639), Klebsiella aerogenes (MT152640), Bacteroides fragilis (MT152909), Clostridium botulinum (MT152910) (Figure 3), hence combined in equal proportion to use as GM inoculum in this study.

\subsection{Effect of High fat diet and GM supplemented diets (HFD/CD) on body weight and body fat}

By examining the effect of HFD and GM with either $\operatorname{diet}(\mathrm{CD} / \mathrm{HFD}$ ) over 12 weeks period, it was observed that both HFD and GM+HFD (G2-G3) combination significantly increased the body weight of mice between two time periods $(\mathrm{P}<0.001)$ (before and after experiment). On the other hand, CD (G1) alone showed no effect on mice body weight, while in combination with GM (G4), it caused significant increase $(\mathrm{P}<0.05)$ in body weight of mice. These results suggested that HFD and GM combination with HFD/CD dispose mice to increase weight gain as observed in our three treatment groups (G2-G4) (Figure $4 a)$. In addition, significant increase $(\mathrm{P}<0.001)$ in body fat of mice fed with HFD alone and GM combined with either of the two diets (HFD/CD; G2-G4) was also observed while comparing with mice kept on CD (G1) only (Figure 4b). Overall, HFD and GM combination with HFD/CD induced significant increase $(\mathrm{P}<0.05)$ in body weight and fat of mice (Figure 4).

\subsection{Effect of High fat diet and GM supplemented diets (HFD/CD) on glucose tolerance}

In order to observe the effect of HFD and GM combination with either of the two diets (HFD/CD), we performed OGTT and ITT. Results are presented in Figure $5 \mathrm{a}$ and $5 \mathrm{~b}$. We observed significant increase $(\mathrm{P}<0.001)$ in glucose levels in mice fed with HFD and GM+HFD (G2-G3) between 15-30 minutes compared to the mice groups fed with $C D$ and $\mathrm{GM}+\mathrm{CD}(\mathrm{G} 1, \mathrm{G} 4)$ (Figure 5a) while performing OGTT. This data indicates that both HFD and GM could deteriorate glucose tolerance, thus causing onset of T2D.

\subsection{Effect of High fat diet and GM supplemented diets (HFD/CD) on serum biochemistry}

To further understand the effect of HFD and synthetic GM combination with either of the two diets (HFD/CD), we analyzed the serum lipid and FFA profile of mice. As shown in Figure 6, plasma TC, TG, LDL and FFA were significantly elevated $(\mathrm{p}<0.05)$ in mice treated with HFD, GM+HFD and $\mathrm{GM}+\mathrm{CD}$ (G2-G4) compared to the mice fed with CD only (G1). There was significant increase in serum HDL in HFD and GM+HFD (G2-G3) only. Serum TC levels showed an increase of 56, 60 and $43 \%$ in three mice groups treated with HFD, GM+HFD and GM+CD (G2-G3) respectively ( $\mathrm{p}<0.001)$. Similarly, TG, LDL and FFA showed an increase of 40-67\% $(\mathrm{p}<0.001)$ in the three treated groups (HFD, GM+HFD and $\mathrm{GM}+\mathrm{CD} ; \mathrm{G} 2-\mathrm{G} 4)$ when compared with group fed with $\mathrm{CD}$ only. Moreover, increase in serum biochemical parameters was highly significant in GM+HFD treated group (G3) followed by HFD group (G2) which was followed by HFD+CD (G4). Significant variation in HDL levels was observed in the two treated groups (HFD; 33\%, GM+HFD; 44\%) vs. the groups treated with $\mathrm{CD}(\mathrm{G} 1)$ and $\mathrm{GM}+\mathrm{CD}(\mathrm{G} 4)$ (Figure 6).

\subsection{Effect of High fat diet and GM supplemented diets (HFD/CD) on inflammatory cytokines}

Gut dysbiosis and T2D are associated with inflammation. This led us to study the levels of inflammatory markers including MCP-1, IL-6 and TNF- $\alpha$ in mice following treatment with CD, HFD, GM+HFD, GM+CD (G1-G4) over 12 week experimental period. Our results showed significantly $(\mathrm{p}<0.05)$ elevated levels of MCP-1, IL-6 and 
TNF- $\alpha$ in mice groups (G2-G4) treated with HFD alone and GM combined with either diet (HFD/CD) compared to the mice treated with CD only (G1) (Figure 7a-c).

\subsection{Effect of High fat diet and GM supplemented diets (HFD/CD) on gut dysbiosis}

To further investigate the effect of HFD and GM on the onset of T2D, we analyzed GM of randomly selected three morphologically different isolates from each group by $16 \mathrm{~S}$ rRNA gene sequencing. Eleven bacteria were identified upto species level using 16S rRNA gene sequencing (Figure 8).

It was observed that microbial diversity decreased in mouse gut following treatment with GM in combination with either diet (HFD/CD). 16S rRNA gene sequencing of selected isolates showed similarity abundance of Bacteroides gallinarum (MT152630), Ruminococcus bromii (MT152631), Lactobacillus acidophilus (MT152632), Parabacteroides gordonii(MT152633), Prevotella copri(MT152634), Lactobacillus gasseri(MT152635) in mice groups (G3-G4) treated with GM+modified diet (HFD/ CD). On the other hand, Akkermansia muciniphila(MT152625), Bacteriodes sp. (MT152626), Bacteroides faecis (MT152627), Bacteroides vulgatus (MT152628), Lactobacillus plantarum (MT152629) were obtained from mice treated with CD (G1) or HFD (G2). Taxonomic identification was based on E-value with reference examples on NCBI databases. Analysis of bacterial diversity revealed that two of the three isolates (B. gallinarum, P. copri and L. acidophilus; 66.66\%) belonged to Bacteriodetes in mice group treated with GM+HFD (G3). Mice group treated with GM+CD (G4) showed more isolates (P. gordonii, R. bromii and L. gasseri; 66.66\%) belonging to Firmicutes. The gut bacteria of mice group treated with CD (G1) showed great diversity of bacteria (B. vulgatus, $L$. plantarum and $A$. muciniphila) belonging to different phyla such as Bacteriodetes, Firmicutes and Verrucomicrobia(33.33\% each) compared to mice group treated with $\operatorname{HFD}(\mathrm{G} 2)$, where bacteria (Bacteriodes sp. and B. faecis) belonging to only phylum Bacteriodetes (100\%) were isolated (Figure 8; Table 2).
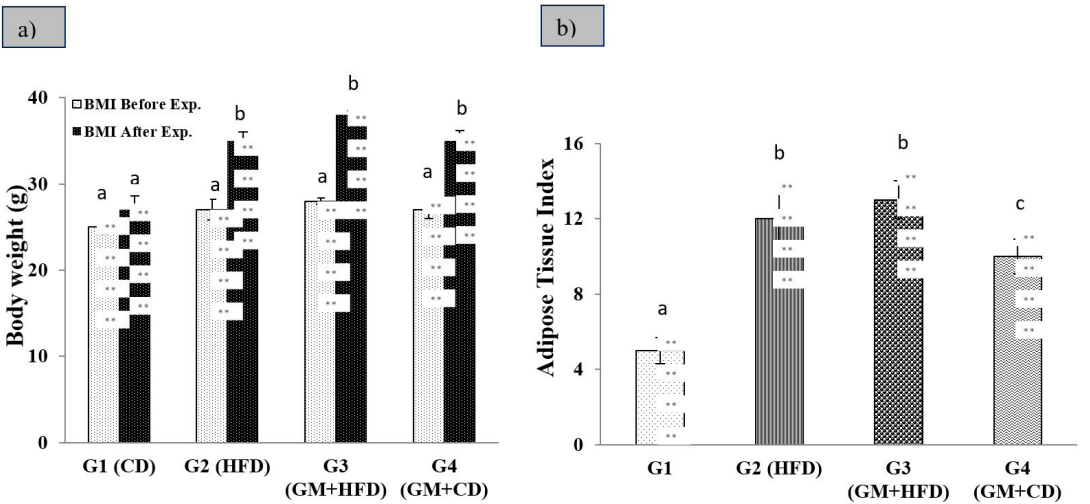

Figure 3. Phylogenetic tree based on $16 \mathrm{~S}$ rRNA gene sequence showed genetic variability among the 07 human fecal bacteria. The tree was constructed using MEGA X software by neighbor-joining tree method. Briefly, human stool samples were obtained from 10 type 2 diabetic (T2D) patients and purified on different media under aerobic and anaerobic conditions. On the basis of visual examination, seven morphologically different and abundant isolates were subjected to $16 \mathrm{~S}$ rRNA gene sequencing.

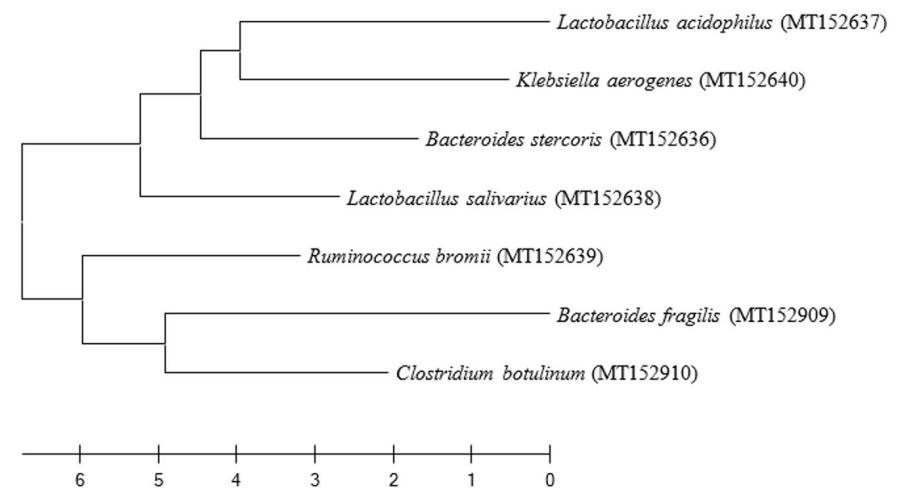

Figure 4. Effect of diet and gut microbiota on (a). Body weights of mice. Mice of groups (G1-G4) were fed with chow diet (CD), high fat diet (HFD), gut microbiota plus high fat diet (GM+HFD) and gut microbiota plus chow diet (GM+CD) respectively for 12 weeks. Body weights were measured at start and end of experiment. (b). Adiposity Index. Adipose tissue index was calculated using formula $(100 \times$ (epididymal fat weight + perirenal fat weight)/body weight). Significant increase $(\mathrm{P}<0.001)$ in body weight (between two time points) and body fat of mice fed with HFD alone and GM combined with either of the two diets (HFD/CD; G2-G4) was observed compared to $C D$ treated group (G1). The data was expressed as mean \pm SEM ( $n-4$ /group). One-way analysis of variance (ANOVA) with post hoc Tukey was used to determine the independent effect of $C D, H F D, G M$ and their interaction on the different measured parameters. Bars with different superscript letters show significance at $\mathrm{P} \leq 0.05$. 


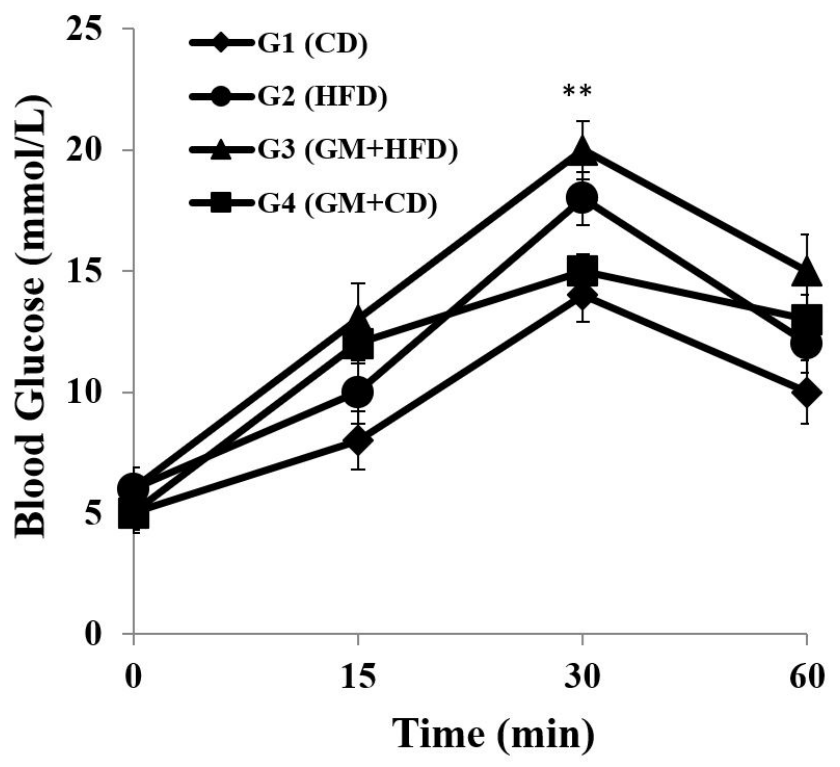

Figure 5. Effect of diet and gut microbiota on oral glucose tolerance test (OGTT). Mice of groups (G1-G4) were fed with chow diet (CD), high fat diet (HFD), gut microbiota plus high fat diet plus (GM+HFD) and gut microbiota plus chow diet (GM+CD) respectively for 12 weeks. Significant increase $(\mathrm{P}<0.001)$ in glucose levels in mice fed with HFD and GM+HFD (G2-G2) between 15-30 minutes compared to the mice groups fed with $\mathrm{CD}$ and $\mathrm{GM}+\mathrm{CD}(\mathrm{G} 1, \mathrm{G} 4)$. The data was expressed as mean $\pm \mathrm{SEM}$ (n-4/group). One-way analysis of variance (ANOVA) with post hoc Tukey was used to determine the independent effect of CD, HFD, GM and their interaction on the different measured parameters. ${ }^{* *}$ indicated significance at $\mathrm{P} \leq 0.05$.

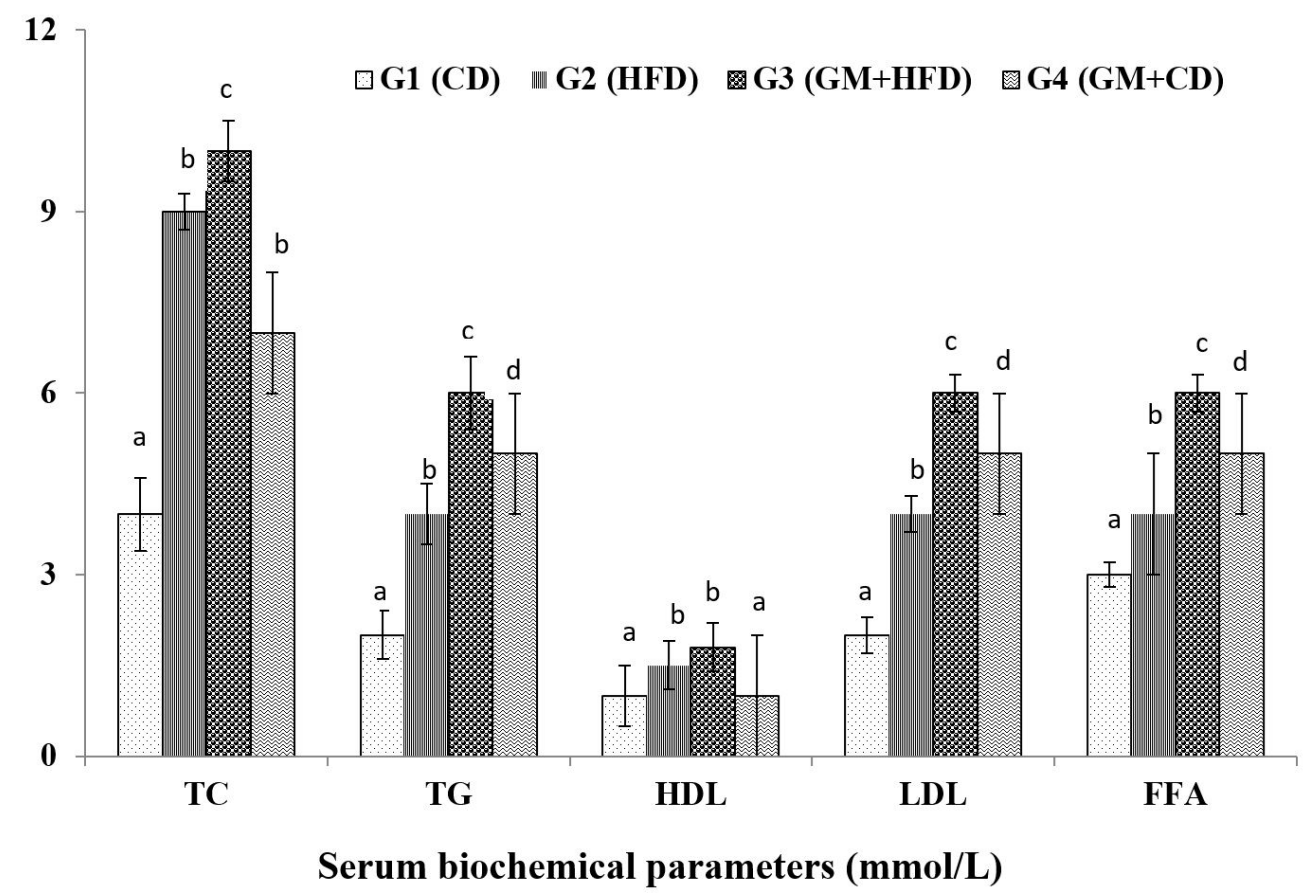

Figure 6. Effect of gut microbiota (GM) and diet on serum biochemical parameters. TC (Total cholesterol); TG (Triglyceride); HDL (High density lipoprotein); LDL (Low density lipoprotein); FFA (Free fatty acids). Mice of groups (G1-G4) were fed with chow diet (CD), high fat $\operatorname{diet}(\mathrm{HFD})$, gut microbiota plus high fat diet (GM+HFD) and gut microbiota plus chow diet (GM+CD) respectively for 12 weeks. Plasma TC, TG, LDL and FFA were significantly elevated ( $\mathrm{p}<0.05)$ in mice treated with HFD, GM+HFD and GM+CD (G2-G4) compared to the mice fed with CD only (G1). There was significant increase in serum HDL in HFD and GM+HFD (G2-G3) only. The data was expressed as mean \pm SEM (n-4/group). One-way analysis of variance (ANOVA) with post hoc Tukey was used to determine the independent effect of CD, HFD, GM and their interaction on the different measured parameters. $\mathrm{P} \leq 0.05$ were considered significant in all tests. 

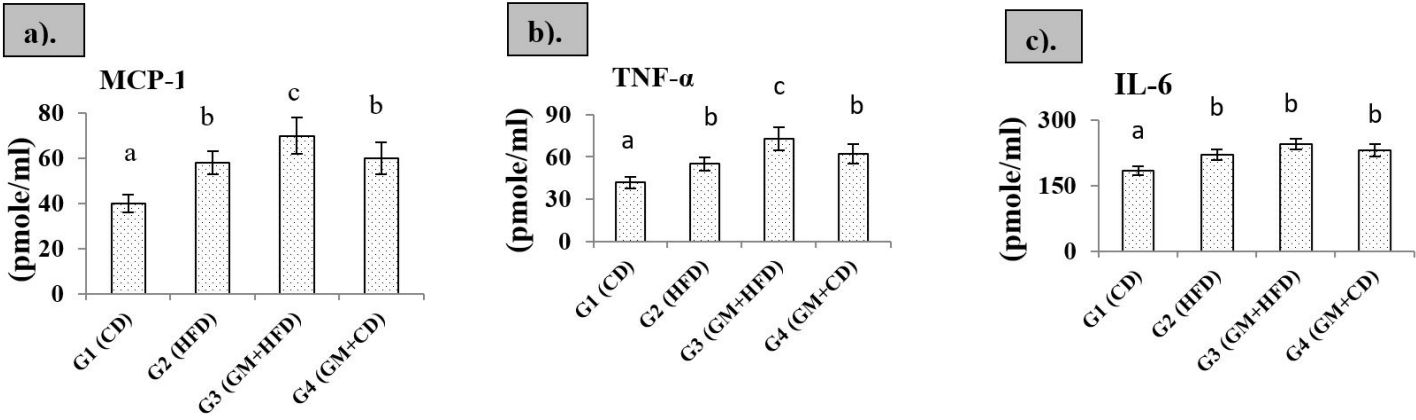

Figure 7. Effect of diet and gut microbiota on serum inflammatory markers. Mice of groups (G1-G4) were fed with chow diet (CD), high fat diet (HFD), gut microbiota plus high fat diet (GM+HFD) and gut microbiota plus chow diet (GM+CD) respectively for 12 weeks. (a). MCP-1, (b). TNF- $\alpha$ and (c). IL-6 were measured using ELISA kit. Significantly ( $p<0.05$ ) elevated levels of MCP-1, IL-6 and TNF- $\alpha$ in mice groups (G2-G4) treated with HFD alone and GM combined with either diet (HFD/CD) compared to the mice treated with CD only (G1). The data was expressed as mean \pm SEM ( $n$-4/group). One-way analysis of variance (ANOVA) with post hoc Tukey was used to determine the independent effect of $C D, H F D, G M$ and their interaction on the different measured parameters. $P \leq 0.05$ were considered significant in all tests.

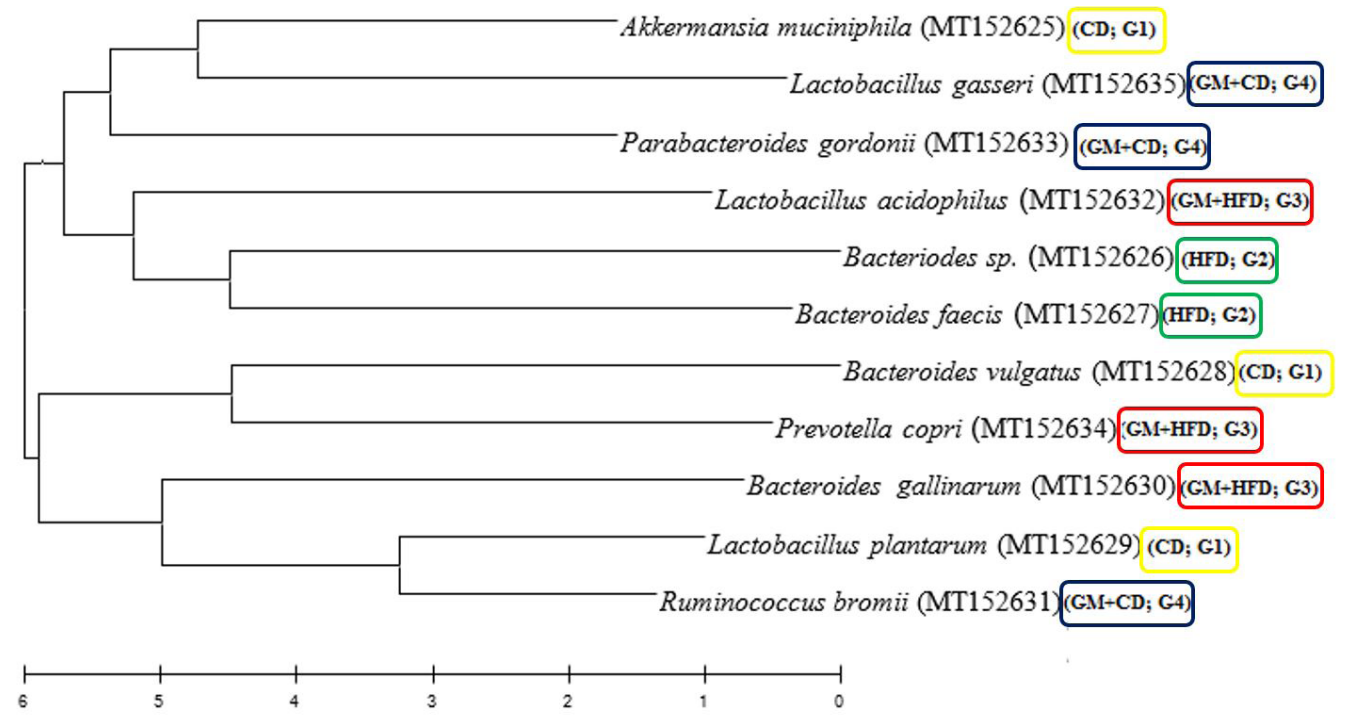

Figure 8. Phylogenetic tree based on $16 \mathrm{~S}$ rRNA gene sequence showed genetic variability among the 11 mice fecal bacteria treated with chow diet (CD), high fat diet (HFD) and synthetic gut microbiota (GM) plus dietary modulation (HFD/CD) for 3 months. The tree was constructed using MEGA X software by neighbor-joining tree method. Yellow squares represent bacteria $(\mathrm{n}=3)$ obtained from $\mathrm{CD}$ treated group (G1), belonging to phyla Bacteriodetes, Firmicutes and Verrucomicrobia. Green squares represent bacteria ( $n=2)$ of HFD treated group (G2), belonging to phylum Bacteriodetes only. Red squares indicate bacteria ( $n=3$ ) obtained from GM+ HFD treated group (G3) belonging to phyla Bacteriodetes ( 2 isolates) and Firmicutes (1). In contrast, blue squares represent bacteria ( $n=3)$ of $G M+C D$ treated group (G4) belonging to phyla Firmicutes (2 isolates) and Bacteriodetes (1).

Table 2. Selective gut microbial diversity and abundance of mice fecal contents.

\begin{tabular}{ccccc}
\hline Mice Fecal isolates & Groups & Phyla & Percent value (\%) & Inference \\
\hline $\begin{array}{c}\text { Bacteroides vulgatus } \\
\begin{array}{c}\text { Lactobacillus } \\
\text { plantarum }\end{array}\end{array}$ & G1 (CD) & Bacteriodetes & 33.33 & Diversified Microbiota \\
$\begin{array}{c}\text { Akkermansia } \\
\text { muciniphila }\end{array}$ & G1 (CD) & Firmicutes & 33.33 & 33.33 \\
\hline
\end{tabular}

CD, chow diet; HFD, high fat diet; GM, gut microbiota. 
Table 2. Continued...

\begin{tabular}{|c|c|c|c|c|}
\hline Mice Fecal isolates & Groups & Phyla & Percent value (\%) & Inference \\
\hline Bacteriodes sp. & G2 (HFD) & Bacteriodetes & \multirow{2}{*}{100} & \multirow{2}{*}{ Major phyla } \\
\hline Bacteroides faecis & G2 (HFD) & Bacteriodetes & & \\
\hline Bacteroides gallinarum & G3 (GM+HFD) & Bacteriodetes & \multirow{2}{*}{66.66} & \multirow{2}{*}{ Abundant phyla } \\
\hline Prevotella copri & G3 (GM+HFD) & Bacteriodetes & & \\
\hline $\begin{array}{l}\text { Lactobacillus } \\
\text { acidophilus }\end{array}$ & G3 (GM+HFD) & Firmicutes & 33.33 & Fewer phylum \\
\hline Lactobacillus gasseri & G4 (GM+CD) & Firmicutes & \multirow{2}{*}{66.66} & \multirow{2}{*}{ Abundant phyla } \\
\hline Ruminococcus bromii & G4 (GM+CD) & Firmicutes & & \\
\hline $\begin{array}{c}\text { Parabacteroides } \\
\text { gordonii }\end{array}$ & G4 (GM+CD) & Bacteriodetes & 33.33 & Fewer phylum \\
\hline
\end{tabular}

CD, chow diet; HFD, high fat diet; GM, gut microbiota.

\section{Discussion}

Trillions of microbes (upto $1.5 \mathrm{~kg}$ ) are present in gut and play important role in human health and infection control (Maruvada et al., 2017). Established evidences show the dysbiosis of gut microbiota plays significant role in onset and progression of various metabolic diseases such as Type 2 Diabetes (T2D) (Zhao, 2013). High fat diet (HFD) was found to be associated with T2D and other metabolic diseases compared to normal chow diet (CD). In this study, we hypothesized that HFD and transfer of synthetic gut microbiota (GM) from T2D patients cause gut dysbiosis which results in insulin resistance and hyperglycemia. This hypothesis was tested by using synthetic HFD and GM combined with either diet (HFD/CD) in mice and monitoring its effects on T2D onset, inflammation as well as limited 16S rRNA gene sequencing of selected mice gut community. Our findings supported the fact that HFD and synthetic GM with either diet (HFD/CD) caused T2D, inflammation and gut dysbiosis in mice.

Total twenty subjects viz., ten suffering with T2D with significantly increased blood glucose levels particularly from 35-75 years of age and 10 control subjects participated in current study. Following age wise comparison of the onset of T2D and sociodemographic data, control subjects were excluded. Initial morphological and cultural screening of twenty bacteria obtained from 10 T2D patients indicated abundance of seven bacteria. 16S rRNA gene sequencing of these seven isolates confirmed close resemblance of these isolates with two phyla including Firmicutes (5 isolates) and Bacteriodetes (2 isolates) with a ratio of 5:2. These findings are similar to observations made by Tam et al. (2018), who reported close association of gut microbes with T2D. Altered microbiota modulates intestinal permeability and results in increased secretions of metabolic endotoxins (lipopolysaccharides, peptidoglycans and flagellin) that cause T2D (Cani et al., 2009; Greiner et al., 2014).

In vivo study using HFD and transfer of synthetic GM bacteria combination with either of the two diets (HFD/ $\mathrm{CD}$ ) resulted increase in weight and body fat index of treated mice groups (G2-G4). Lima et al. (2018), observed that mothers exposed to HFD during pregnancy and lactation showed increased body weight, adipose tissue and hypercholesterolemia in neonatal rats. Further, we observed elevated blood glucose in HFD and GM+modified diets (HFD/CD) treated mice groups (G2-G4). These findings are consistent with previous report by Zhou et al. (2019), who demonstrated that mice fed with HFD for 3 months showed increased levels of FBG, HbA1C and impaired tolerance to glucose. Regarding biochemical picture, our results also showed elevated TC, TG, LDL and FFA levels in HFD and GM+modified diet (HFD/CD) treated mice groups (G2-G4). Interestingly, HDL level showed significant elevation in groups treated with HFD alone and combined with GM (G2-G3). Usually, both weight and metabolism of glycolipid are interlinked (Gurung et al., 2020), and any alteration in either affects the other. Another possibility of increased lipid levels, body fat mass, and body weight might be due to direct effect of GM on spleen, as established by Gong et al. (2013), who demonstrated that altered GM affects the function of spleen, causing change in body weight and lipid metabolism.

In order to assess the inflammation, we measured the levels of serum inflammatory markers including MCP-1, (b) IL-6, and (c) TNF- $\alpha$. Increased level of these markers indicated inflammation, which could have caused insulin resistance and T2D etiology in experimental mice (2016). It is very possible, that HFD and synthetic GM combination with modified diet particularly with HFD have resulted in gut dysbiosis, resulted in more lipopolysaccharides (LPS) production which are potent stimulators of inflammation and can exhibit endotoxemia (Jakobsson et al., 2015), thus leading to development of diabetes. We did not study LPS or endotoxemia in this study, however possibly these inflammatory markers have been released by mice intestine in response to various bacterial antigens and have adverse effects on metabolism of glucose (Netto Candido et al., 2018). Previously, in one study IL-1 $\beta$ was observed to be associated with beta cell toxicity and insulin resistance, as leading factors of T2D disease (Cao et al., 2019)

Our next and final step was to analyse the effect of HFD and synthetic GM combination with modified diet (HFD/CD) on treated mice gut community. We already knew that HFD and GM are closely related and causative factors for metabolic disorders such as T2D. Using 16S rRNA sequencing of selected 11 fecal isolates from four treated mice groups (CD, G1; HFD, G2; GM+HFD, G3; GM+CD, G4), compositional changes were observed in microbiota of mice gut. Among identified eleven isolates including 
Bacteroides gallinarum, Ruminococcus bromii, Lactobacillus acidophilus, Parabacteroides gordonii, Prevotella copri, Lactobacillus gasseri, Akkermansia muciniphila, Bacteriodes sp., Bacteriodes faecis, Bacteriodes vulgatus, Lactobacillus plantarum, two isolates (Bacteriodes sp. and B. faecis) were found to belong to phylum Bacteriodetes (100\%) from HFD treated group (G2); two of the three isolates (B. gallinarum, P. copri and L. acidophilus) to Bacteriodetes (66.66\%) from mice group treated with GM+HFD (G3) and more isolates (P. gordonii, R. bromii and L. gasseri) to Firmicutes (66.66\%) from mice group treated with $\mathrm{GM}+\mathrm{CD}$ (G4) were identified compared to mice group treated with CD (G1), where three bacteria linked to diverse phyla such as Bacteriodetes (33.33\%), Firmicutes (33.33\%) and Verrucomicrobia (33.33\%) were isolated (Table 2). Our findings of more altered Bacteriodetes/Firmicutes ratio in mice treated with HFD and GM+modified diets (HFD/ CD) are similar to Larsen et al. (2010), who noticed that Firmicutes/Bacteroidetes ratio affects plasma glucose levels as well as insulin tolerance. Similarly, Seo et al. (2015) demonstrated increased Firmicutes/Bacteroidetes or Bacteroidetes/Prevotella as possible signatures of T2D. A recent study in diabetic rats also concluded that variations in Firmicutes/Bacteroidetes ratio might be the explanation of partial diabetes progression (Zhou et al., 2019). Likewise, Gurung et al. (2020) reported negative association of bacterial genera such as Akkermansia, Bacteroides, Bifidobacterium, Faecalibacterium and Roseburia with T2D compared to genera of Blautia, Ruminococcus and Fusobacterium which showed positive association with T2D. All this data conclusively indicate that alteration in Bacteroidetes and Firmicutes are important reasons of T2D etiology and progression (Tilg and Moschen, 2014).

Our findings indicated that HFD and synthetic GM combination with modified diet (HFD/CD) might have exacerbated the inflammation in mice as observed by Liu et al. (2019). Mice treated with CD only showed presence of A. muciniphila. This bacterium is considered to be necessary for healthy host glucose metabolism and negative effects on T2D (Everard et al., 2013; Greer et al., 2016; Plovier et al., 2017; Plovier et al., 2017). Besides, increased Lactobacilli observed in our results have previously reported in obese individuals (Ali et al., 2013; Arora and Bäckhed, 2016). There is controversial data on their role in improving insulin resistance, glucose tolerance and gut health depending upon species (Ali et al., 2013; Kang et al., 2013; Chen et al., 2018). Some species, for example L. gasseri and $L$. plantarum, isolated in this study has the probiotic potential and possess anti obese effect, protecting the intestinal barrier and reducing inflammation (Kang et al., 2013; Chen et al., 2018). While role of L. acidophilus is under debate. Yan et al. (2019) observed positive role of L. acidophilus in regulating glucose and lipid metabolism thus controlling T2D which is in contrast to the findings by Ali et al. (2013), who reported significantly increased fecal L. acidophilus among uncontrolled diabetic patients and its relationship with enhance phagocytic activity by polymorpho nuclear leucocytes.

Diversity of gut microbiota is strictly controlled by dietary interventions, lifestyle and antidiabetic drugs. Orally-taken antidiabetic medicines reach the gastrointestinal tract and alter the intestinal microbiota. Since gut microflora encoded enzymes have the potential to influence the pharmacogenetics of drugs and their bioavialability (Kyriachenko et al., 2019). For example, treatment with metformin, most extensively used antidiabetic drug resulted in increased number of short chain fatty acids (SCFA) producing bacteria including (Prevotella, Bacteroides, Butyricoccus and Blautia etc.) with positive effects on the Proteobacteria phylum and Lactobacillus genera (Montandon and Jornayvaz, 2017). Furthermore, gut microbiota cause attenuation of side effects by glucose-lowering medicines, thus offering benefits to diabetic patients (Kobyliak et al., 2018). A growing number of data support the role of gut microbiome in hormone secretions and its diversification with brain microstructure by producing various neuronal compounds such as 5-HT etc., assigning unique signatures to brain for differentiation between obese $v s$. lean subjects (Martin et al., 2018). This study supports the fact that not only the gut microflora but also the diet plays major role in the aggravation of metabolic disturbance, although the molecular mechanism requires further investigation.

Type 2 diabetes is a multifactorial disease and can cause life threatening complications. This study suggests that human gut bacteria coctail used to induce T2D in mice possess ability to survive through gastroenetric transit, as observed by relative abundance in mice feces. Previously, Nagpal et al. (2018), published that lactic acid bacteria (L. acidophilus and L. salivarius) are established for tolerance to orogastrointestinal transit such as high acid and bile concentrations as well as adherence to human gastrointestinal mucosa. Likewise, Bacteroides species is also abundantly found in human gut (Sato et al., 2020). Acid resistance in $B$. fragilis is conferred by presence of glutamic acid decarboxylase (GAD) enzymes, which are the metabolic components of glutamate dependent system that provide protection to $\mathrm{pH}$ 2.0. Similarly, GAD activity reported in previously E. aerogenes ensures its survival through gastric transit (Park and Diez-Gonzalez, 2004). Similarly, $R$. bromii is prevalent in human colon. Zheng et al. (2017) reported an increase in Ruminococcus sp. following administration of HFD and bile acid. Authors observed this microbe as gut symbiont that survives on host mucin and dietary starch. Clostridium botulinum cannot survive in acidic environment of stomach in vegetative form but its spores are highly resistant against heat and all treatments, thus enabling bacteria to survive and establish infection (Chellapandi and Prisilla, 2018).

Our findings suggest that both diet and gut microbe coctail caused higher blood glucose, plasma insulin concentration and inflammation, each acting as trigger to T2D onset. We further confirm that consumption of small number of T2D gut microbe coctail and high fat feeding can result in significant changes in gut dysbiosis in mice. This is similar to observations made by Messer and Chang (2018), who reported that microbes of gut community have close functional relations and even small number of microbes and/or their functions could have serious impacts on total community. That's why, specific strategies to modify the gut microbiota should be used because gut microbiota modulation reduce the incidence of T2D by lowering the effect of HFD. Similarly, probiotics should also be used as supplements because they are helpful in reducing the risk of developing T2D by regulating the 
lipid metabolism which results in lower cholesterol and LDL in blood serum along with controlled inflammation.

\section{Acknowledgements}

This study was funded by ORIC Project No. 239/ORIC/19, GC University Lahore.

\section{References}

ALI, F.H.A., ASHOUR, Z.A., SHAHIN, R.Y., ZAKI, W.K., RAGAB, S.B. and ATTIA, M.Y., 2013. Role of intestinal microflora (Lactobacillus Acidophilus) in phagocytic function of leukocytes in type 2 diabetic patients. The Egyptian Journal of Medical Human Genetics, vol. 14, no. 1, pp. 95-101. http://dx.doi.org/10.1016/j. ejmhg.2012.10.003.

AN, Y., LI, Y., WANG, X., CHEN, Z., XU, H., WU, L., LI, S., WANG, C., LUAN, W., WANG, X., LIU, M., TANG, X. and YU, L., 2018. Cordycepin reduces weight through regulating gut microbiota in high-fat diet-induced obese rats. Lipids in Health and Disease, vol. 17, no. 1, pp. 276. http://dx.doi.org/10.1186/s12944-018-0910-6. PMid:30522511.

ARORA, T. and BÄCKHED, F., 2016. The gut microbiota and metabolic disease: current understanding and future perspectives. Journal of Internal Medicine, vol. 280, no. 4, pp. 339-349. http://dx.doi. org/10.1111/joim.12508. PMid:27071815.

BHUTE, S.S., SURYAVANSHI, M.V., JOSHI, S.M., YAJNIK, C.S., SHOUCHE, Y.S. and GHASKADBI, S.S., 2017. Gut microbial diversity assessment of Indian type-2-diabetics reveals alterations in eubacteria, archaea, and eukaryotes. Frontiers in Microbiology, vol. 8, pp. 214. http://dx.doi.org/10.3389/fmicb.2017.00214. PMid:28261173.

CANFORA, E.E., MEEX, R., VENEMA, K. and BLAAK, E.E., 2019. Gut microbial metabolites in obesity, NAFLD and T2DM. Nature Reviews. Endocrinology, vol. 15, no. 5, pp. 261-273. http://dx.doi. org/10.1038/s41574-019-0156-z. PMid:30670819.

CANI, P.D., POSSEMIERS, S., VAN DE WIELE, T., GUIOT, Y., EVERARD, A., ROTTIER, O., GEURTS, L., NASLAIN, D., NEYRINCK, A.M., LAMBERT, D.M., MUCCIOLI, G.G. and DELZENNE, N.M., 2009. Changes in gut microbiota control inflammation in obese mice through a mechanism involving GLP-2-driven improvement of gut permeability. Gut, vol. 58, no. 8, pp. 1091-1103. http:// dx.doi.org/10.1136/gut.2008.165886. PMid:19240062.

CAO, Y., YAO, G., SHENG, Y., YANG, L., WANG, Z., YANG, Z., ZHUANG, P. and ZHANG, Y., 2019. JinQi Jiangtang tablet regulates gut microbiota and improve insulin sensitivity in type 2 diabetes mice. Journal of Diabetes Research, vol. 2019, pp. 1872134. http:// dx.doi.org/10.1155/2019/1872134. PMid:30733971.

CHELLAPANDI, P. and PRISILLA, A., 2018. Clostridium botulinum type A-virulome-gut interactions: a systems biology insight. Human Microbiome Journal, vol. 7, pp. 15-22. http://dx.doi. org/10.1016/j.humic.2018.01.003.

CHEN, X., TAN, F., YI, R., MU, J., ZHAO, X. and YANG, Z., 2018. Effects of Lactobacillus on mice with diabetes induced by high-fat diet with streptozotocin (STZ). Applied Sciences, vol. 8, no. 8, pp. 1249. http://dx.doi.org/10.3390/app8081249.

ELLEKILDE, M., SELFJORD, E., LARSEN, C.S., JAKESEVIC, M., RUNE, I., TRANBERG, B., VOGENSEN, F.K., NIELSEN, D.S., BAHL, M.I., LICHT, T.R., HANSEN, A.K. and HANSEN, C.H., 2014. Transfer of gut microbiota from lean and obese mice to antibiotic-treated mice. Scientific Reports, vol. 4, no. 1, pp. 5922. http://dx.doi. org/10.1038/srep05922. PMid:25082483.
EVERARD, A. and CANI, P.D., 2013. Diabetes, obesity and gut microbiota. Best Practice \& Research. Clinical Gastroenterology, vol. 27, no. 1, pp. 73-83. http://dx.doi.org/10.1016/j.bpg.2013.03.007. PMid:23768554.

EVERARD, A., BELZER, C., GEURTS, L., OUWERKERK, J.P., DRUART, C., BINDELS, L.B., GUIOT, Y., DERRIEN, M., MUCCIOLI, G.G., DELZENNE, N.M., DE VOS, W.M. and CANI, P.D., 2013. Cross-talk between Akkermansia muciniphila and intestinal epithelium controls diet-induced obesity. Proceedings of the National Academy of Sciences of the United States of America, vol. 110, no. 22, pp. 9066-9071. http://dx.doi.org/10.1073/pnas.1219451110. PMid:23671105.

GONG, C.D., WU, Q.L., CHEN, Z., ZHANG, D., ZHAO, Z.Y. and PENG, Y.M., 2013. Glycolipid metabolic status of overweight/obese adolescents aged 9- to 15-year-old and the BMI-SDS/BMI cutoff value of predicting dyslipidemiain boys, Shanghai, China: a cross-sectional study. Lipids in Health and Disease, vol. 12, no. 1, pp. 129. http://dx.doi.org/10.1186/1476-511X-12-129. PMid:23984682.

GREER, R.L., DONG, X., MORAES, A.C.F., ZIELKE, R.A., FERNANDES, G.R., PEREMYSLOVA, E., VASQUEZ-PEREZ, S., SCHOENBORN, A.A., GOMES, E.P., PEREIRA, A.C., FERREIRA, S.R., YAO, M., FUSS, I.J., STROBER, W., SIKORA, A.E., TAYLOR, G.A., GULATI, A.S., MORGUN, A. and SHULZHENKO, N., 2016. Akkermansia muciniphila mediates negative effects of IFN $\gamma$ on glucose metabolism. Nature Communications, vol. 7, no. 1, 13329. http:// dx.doi.org/10.1038/ncomms13329. PMid:27841267.

GREINER, T.U., HYÖTYLÄINEN, T., KNIP, M., BACKHED, F. and ORESIC, M., 2014. The gut microbiota modulates glycaemic control and serum metabolite profiles in non-obese diabetic mice. PLoS One, vol. 9, no. 11, pp. e110359. http://dx.doi.org/10.1371/journal. pone.0110359. PMid:25390735.

GURUNG, M., LI, Z., YOU, H., RODRIGUES, R., JUMP, D.B., MORGUN, A. and SHULZHENKO, N., 2020. Role of gut microbiota in type 2 diabetes pathophysiology. EBioMedicine, vol. 51, pp. 102590. http://dx.doi.org/10.1016/j.ebiom.2019.11.051. PMid:31901868.

JAKOBSSON, H.E., RODRÍGUEZ-PIÑEIRO, A.M., SCHÜTTE, A., ERMUND, A., BOYSEN, P., BEMARK, M., SOMMER, F., BÄCKHED, F., HANSSON, G.C. and JOHANSSON, M.E., 2015. The composition of the gut microbiota shapes the colon mucus barrier. EMBO Reports, vol. 16, no. 2, pp. 164-177. http://dx.doi.org/10.15252/ embr.201439263. PMid:25525071.

KANG, J.H., YUN, S.I., PARK, M.H., PARK, J.H., JEONG, S.Y. and PARK, H.O., 2013. Anti-obesity effect of Lactobacillus gasseri BNR17 in high-sucrose diet-induced obese mice. PLoS One, vol. 8, no. 1, pp. e54617. http://dx.doi.org/10.1371/journal.pone.0054617. PMid:23382926.

KARLSSON, F.H., TREMAROLI, V., NOOKAEW, I., BERGSTRÖM, G., BEHRE, C.J., FAGERBERG, B., NIELSEN, J. and BÄCKHED, F., 2013. Gut metagenome in European women with normal, impaired and diabetic glucose control. Nature, vol. 498, no. 7452, pp. 99103. http://dx.doi.org/10.1038/nature12198. PMid:23719380.

KOBYLIAK, N., ABENAVOLI, L., FALALYEYEVA, T. and BEREGOVA, T., 2018. Efficacy of Probiotics and Smectite in Rats with NonAlcoholic Fatty Liver Disease. Annals of Hepatology, vol. 17, no. 1, pp. 153-161. http://dx.doi.org/10.5604/01.3001.0010.7547. PMid:29311399.

KYRIACHENKO, Y., FALALYEYEVA, T., KOROTKYI, O., MOLOCHEK, N. and KOBYLIAK, N., 2019. Crosstalk between gut microbiota and antidiabetic drug action. World Journal of Diabetes, vol. 10, no. 3, pp. 154-168. http://dx.doi.org/10.4239/wjd.v10.i3.154. PMid:30891151.

LARSEN, N., VOGENSEN, F.K., VAN DEN BERG, F.W.J., NIELSEN, D.S., ANDREASEN, A.S., PEDERSEN, B.K., AL-SOUD, W.A., 
SØRENSEN, S.J., HANSEN, L.H. and JAKOBSEN, M., 2010. Gut microbiota in human adults with type 2 diabetes differs from non-diabetic adults. PLoS One, vol. 5, no. 2, pp. e9085. http:// dx.doi.org/10.1371/journal.pone.0009085. PMid:20140211.

LIMA, M.S., PEREZ, G.S., MORAIS, G.L., SANTOS, L.S., CORDEIRO, G.S., COUTO, R.D., DEIRÓ, T.C.B.J., LEANDRO, C.G. and BARRETOMEDEIROS, J.M., 2018. Effects of maternal high fat intake during pregnancy and lactation on total cholesterol and adipose tissue in neonatal rats. Brazilian Journal of Biology $=$ Revista Brasileira de Biologia, vol. 78, no. 4, pp. 615-618. http://dx.doi. org/10.1590/1519-6984.166788. PMid:29319751

LIU, S., QIN, P. and WANG, J., 2019. High-fat diet alters the intestinal microbiota in streptozotocin-induced type 2 diabetic mice. Microorganisms, vol. 7, no. 6, pp. 176. http://dx.doi.org/10.3390/ microorganisms7060176. PMid:31208113.

MARCHESI, J.R., ADAMS, D.H., FAVA, F., HERMES, G.D., HIRSCHFIELD, G.M., HOLD, G., QURAISHI, M.N., KINROSS, J., SMIDT, H., TUOHY, K.M., THOMAS, L.V., ZOETENDAL, E.G. and HART, A., 2016. The gut microbiota and host health: a new clinical frontier. Gut, vol. 65, no. 2, pp. 330-339. http://dx.doi.org/10.1136/ gutjnl-2015-309990. PMid:26338727.

MARTIN, C.R., OSADCHIY, V., KALANI, A. and MAYER, E.A., 2018. The brain-gut-microbiome axis. Cellular and Molecular Gastroenterology and Hepatology, vol. 6, no. 2, pp. 133-148. http://dx.doi.org/10.1016/j.jcmgh.2018.04.003. PMid:30023410.

MARUVADA, P., LEONE, V., KAPLAN, L.M. and CHANG, E.B., 2017. The human microbiome and obesity: moving beyond associations. Cell Host E'Microbe, vol. 22, no. 5, pp. 589-599. http://dx.doi. org/10.1016/j.chom.2017.10.005. PMid:29120742.

MESSER, J.S. and CHANG, E.B. 2018. Microbial physiology of the digestive tract and its role in inflammatory bowel diseases. In: H.M. SAID, ed. Physiology of the gastrointestinal tract. London: Academic Press, pp. 795-810. http://dx.doi.org/10.1016/B9780-12-809954-4.00036-0.

MONTANDON, S.A. and JORNAYVAZ, F.R., 2017. Effects of antidiabetic drugs on gut microbiota composition. Genes, vol. 8, no. 10, pp. 250. PMid:28973971.

NAGPAL, R., WANG, S., AHMADI, S., HAYES, J., GAGLIANO, J., SUBASHCHANDRABOSE, S., KITZMAN, D.W., BECTON, T., READ, R. and YADAV, H., 2018. Human-origin probiotic cocktail increases short-chain fatty acid production via modulation of mice and human gut microbiome. Scientific Reports, vol. 8, no. 1, pp. 12649. http://dx.doi.org/10.1038/s41598-018-30114-4. PMid:30139941.

NETTO CANDIDO, T.L., BRESSAN, J. and ALFENAS, R.C.G., 2018. Dysbiosis and metabolic endotoxemia induced by high-fat diet. Nutrición Hospitalaria, vol. 35, no. 6, pp. 1432-1440. http:// dx.doi.org/10.20960/nh.1792. PMid:30525859.

PARK, G.W. and DIEZ-GONZALEZ, F., 2004. A novel glutamatedependent acid resistance among strains belonging to the Proteeae tribe of Enterobacteriaceae. FEMS Microbiology Letters, vol. 237, no. 2, pp. 303-309. http://dx.doi. org/10.1111/j.1574-6968.2004.tb09711.x. PMid:15321677.

PARKS, B.W., NAM, E., ORG, E., KOSTEM, E., NORHEIM, F., HUI, S.T., PAN, C., CIVELEK, M., RAU, C.D., BENNETT, B.J., MEHRABIAN, M., URSELL, L.K., HE, A., CASTELLANI, L.W., ZINKER, B., KIRBY, M., DRAKE, T.A., DREVON, C.A., KNIGHT, R., GARGALOVIC, P., KIRCHGESSNER, T., ESKIN, E. and LUSIS, A.J., 2013. Genetic control of obesity and gut microbiota composition in response to high-fat, high-sucrose diet in mice. Cell Metabolism, vol. 17, no. 1, pp. 141-152. http://dx.doi.org/10.1016/j.cmet.2012.12.007. PMid:23312289.
PLOVIER, H., EVERARD, A., DRUART, C., DEPOMMIER, C., VAN HUL, M., GEURTS, L., CHILLOUX, J., OTTMAN, N., DUPARC, T., LICHTENSTEIN, L., MYRIDAKIS, A., DELZENNE, N.M., KLIEVINK, J., BHATTACHARJEE, A., VAN DER ARK, K.C.H., AALVINK, S., MARTINEZ, L.O., DUMAS, M.-E., MAITER, D., LOUMAYE, A., HERMANS, M.P., THISSEN, J.-P., BELZER, C., DE VOS, W.M. and CANI, P.D., 2017. A purified membrane protein from Akkermansia muciniphila or the pasteurized acterium improves metabolism in obese and diabetic mice. Nature Medicine, vol. 23, no. 1, pp. 107-113. http://dx.doi.org/10.1038/nm.4236. PMid:27892954.

QIN, J., LI, Y., CAI, Z., LI, S., ZHU, J., ZHANG, F., LIANG, S., ZHANG, W., GUAN, Y., SHEN, D., PENG, Y., ZHANG, D., JIE, Z., WU, W., QIN, Y., XUE, W., LI, J., HAN, L., LU, D., WU, P., DAI, Y., SUN, X., LI, Z., TANG, A., ZHONG, S., LI, X., CHEN, W., XU, R., WANG, M., FENG, Q., GONG, M., YU, J., ZHANG, Y., ZHANG, M., HANSEN, T., SANCHEZ, G., RAES, J., FALONY, G., OKUDA, S., ALMEIDA, M., LECHATELIER, E., RENAULT, P., PONS, N., BATTO, J.M., ZHANG, Z., CHEN, H., YANG, R., ZHENG, W., LI, S., YANG, H., WANG, J., EHRLICH, S.D., NIELSEN, R., PEDERSEN, O., KRISTIANSEN, K. and WANG, J., 2012. A metagenome-wide association study of gut microbiota in type 2 diabetes. Nature, vol. 490, no. 7418, pp. 55-60. http://dx.doi.org/10.1038/nature11450. PMid:23023125.

RASTELLI, M., KNAUF, C. and CANI, P.D., 2018. Gut microbes and health: a focus on the mchanisms linking microbes, obesity, and related disorders. Obesity, vol. 26, no. 5, pp. 792-800. http:// dx.doi.org/10.1002/oby.22175. PMid:29687645.

REGGINATO, A., CUNICO, L., BERTONCELLO, K.T., SCHINDLER, M.S.Z., CHITOLINA, R., MARINS, K., ZANATTA, A.P., CALISTO, J.F., OLIVEIRA, J.V., MAGRO, J.D. and ZANATTA, L., 2021. Antidiabetic and hypolipidemic potential of Campomanesia xanthocarpa seed extract obtained by supercritical $\mathrm{CO}_{2}$. Brazilian Journal of Biology = Revista Brasileira de Biologia, vol. 81, no. 3, pp. 621-631. http://dx.doi.org/10.1590/1519-6984.227388. PMid:32876168.

SATO, M., KAJIKAWA, K., KUMON, T., WATANABE, D., TAKASE, R. and HASHIMOTO, W., 2020. Mutually beneficial symbiosis between human and gut-dominant bacteroides species through bacterial assimilation of host mucosubstances. bioRxiv.

SEO, D.B., JEONG, H.W., CHO, D., LEE, B.J., LEE, J.H., CHOI, J.Y., BAE, I.H. and LEE, S.J., 2015. Fermented green tea extract alleviates obesity and related complications and alters gut microbiota composition in diet-induced obese mice. Journal of Medicinal Food, vol. 18, no. 5, pp. 549-556. http://dx.doi.org/10.1089/ jmf.2014.3265. PMid:25764354.

SIRCANA, A., FRAMARIN, L., LEONE, N., BERRUTTI, M., CASTELLINO, F., PARENTE, R., DE MICHIELI, F., PASCHETTA, E. and MUSSO, G., 2018. Altered gut microbiota in type 2 diabetes: just a coincidence? Current Diabetes Reports, vol. 18, no. 10, pp. 98. http://dx.doi.org/10.1007/s11892-018-1057-6. PMid:30215149.

TAM, J., HOFFMANN, T., FISCHER, S., BORNSTEIN, S., GRASSLER, J. and NOACK, B., 2018. Obesity alters composition and diversity of the oral microbiota in patients with type 2 diabetes mellitus independently of glycemic control. PLoS One, vol. 13, no. 10, pp. e0204724. http://dx.doi.org/10.1371/journal.pone.0204724. PMid:30273364.

TILG, H. and MOSCHEN, A.R., 2014. Microbiota and diabetes: an evolving relationship. Gut, vol. 63, no. 9, pp. 1513-1521. http:// dx.doi.org/10.1136/gutjnl-2014-306928. PMid:24833634.

VRIEZE, A., VAN NOOD, E., HOLLEMAN, F., SALOJARVI, J., KOOTTE, R.S., BARTELSMAN, J.F., DALLINGA-THIE, G.M., ACKERMANS, M.T., SERLIE, M.J., OOZEER, R., DERRIEN, M., DRUESNE, A., VAN HYLCKAMA VLIEG, J.E., BLOKS, V.W., GROEN, A.K., HEILIG, H.G., ZOETENDAL, E.G., STROES, E.S., DE VOS, W.M., HOEKSTRA, J.B. and NIEUWDORP, M., 2012. Transfer of intestinal microbiota from lean donors increases insulin sensitivity in individuals 
with metabolic syndrome. Gastroenterology, vol. 143, no. 4, pp. 913-916. http://dx.doi.org/10.1053/j.gastro.2012.06.031. PMid:22728514.

WU, R., ZHAO, D., AN, R., WANG, Z., LI, Y., SHI, B. and NI, Q., 2019. Linggui Zhugan (LGZG) formula improves glucose and lipid levels and alters gut microbiota in high-fat diet-induced diabetic mice. Frontiers in Physiology, vol. 10, pp. 918. http://dx.doi. org/10.3389/fphys.2019.00918. PMid:31396097.

YAN, F., LI, N., SHI, J., LI, H., YUE, Y., JIAO, W., WANG, N., SONG, Y., HUO, G. and LI, B., 2019. Lactobacillus acidophilus alleviates type 2diabetes by regulating hepatic glucose, lipid metabolism and gut microbiota in mice. Food E Function, vol. 10, no. 9, pp. 58045815. http://dx.doi.org/10.1039/C9FO01062A. PMid:31461095.
ZHAO, L., 2013. The gut microbiota and obesity: from correlation to causality. Nature Reviews. Microbiology, vol. 11, no. 9, pp. 639647. http://dx.doi.org/10.1038/nrmicro3089. PMid:23912213.

ZHENG, X., HUANG, F., ZHAO, A., LEI, S., ZHANG, Y., XIE, G., CHEN, T., QU, C., RAJANI, C., DONG, B., LI, D. and JIA, W., 2017. Bile acid is a significant host factor shaping the gut microbiome of diet-induced obese mice. BMC Biology, vol. 15, no. 1, pp. 120. http://dx.doi.org/10.1186/s12915-017-0462-7. PMid:29241453.

ZHOU, W., XU, H., ZHAN, L., LU, X. and ZHANG, L., 2019. Dynamic development of fecal microbiome during the progression of diabetes mellitus in Zucker diabetic fatty rats. Frontiers in Microbiology, vol. 10, pp. 232. http://dx.doi.org/10.3389/ fmicb.2019.00232. PMid:30837966. 